\title{
Obesity status is a risk factor for secondary surgery after neurolysis, direct nerve repair or nerve grafting in traumatic brachial plexus injury: a retrospective cohort study
}

Pichitchai Atthakomol ${ }^{1,2,3^{*}}$, Kamilcan Oflazoglu' ${ }^{1}$, Kyle R. Eberlin ${ }^{1}$, Jonathan Winograd ${ }^{1}$, Neal C. Chen ${ }^{1}$ and Sang-Gil Lee ${ }^{1}$

\begin{abstract}
Background: The objective of the study was to investigate the association between obesity and the presence of secondary surgery following neurolysis, direct nerve repair, or nerve grafting in patients with traumatic brachial plexus injury.

Methods: In this retrospective chart review spanning two Level I medical centers in a single metropolitan area, 57 patients who underwent neurolysis, direct nerve repair, or nerve grafting for brachial plexus injuries between 2002 and 2015 were identified. Risk regression analysis was used to evaluate the association between obesity status and secondary surgery.

Results: After controlling for the confounding variables of age, high energy injury, associated shoulder dislocation and associated clavicle fracture using multivariate regression (risk regression), the risk ratio of secondary surgery in obese patients compared to non-obese patients was $6.99(P=0.028)$. The most common secondary surgery was tendon or local muscle transfer.
\end{abstract}

Conclusions: There is an increased risk of secondary surgery in obese patients compared to non-obese patients of the same age and with the same severity of injury. The increased risk may be due to challenges related to powering a heavier upper extremity. A weight reduction program might be considered as part of the preoperative strategy.

Keywords: Obesity, Risk factor, Secondary surgery, Neurolysis, Nerve repair, Nerve grafting, Brachial plexus injury

\section{Background}

Prior to the advent and growth in popularity of nerve transfers, traumatic injuries of the plexus were generally treated with direct repair, nerve grafting, or neurolysis. During exploration of a brachial plexus injury, the nerve can be grossly transected, a traction injury with a well-

\footnotetext{
* Correspondence: p.atthakomol@gmail.com

'Department of Orthopaedic Surgery, Massachusetts General Hospital, Boston, MA, USA

${ }^{2}$ Department of Orthopaedics, Faculty of Medicine, Chiang Mai University, Chiang Mai, Thailand

Full list of author information is available at the end of the article
}

defined zone of injury, or a post-ganglionic neuroma in continuity with electrical evidence of physiological continuity [1-6]. The mechanism of injury, severity of injury, and intraoperative findings guide operative decision making $[1,4,7-10]$.

Prior studies on neurolysis, direct nerve repair, nerve grafting or nerve transfer in traumatic brachial plexus injury have mainly focused on functional outcomes, typically using the Medical Research Council (MRC) scale. Poor outcomes (motor power < grade 3 ) has been reported in up to $40 \%$ of patients $[2,4,7,11-16]$.

(c) The Author(s). 2020 Open Access This article is licensed under a Creative Commons Attribution 4.0 International License, which permits use, sharing, adaptation, distribution and reproduction in any medium or format, as long as you give appropriate credit to the original author(s) and the source, provide a link to the Creative Commons licence, and indicate if changes were made. The images or other third party material in this article are included in the article's Creative Commons licence, unless indicated otherwise in a credit line to the material. If material is not included in the article's Creative Commons licence and your intended use is not permitted by statutory regulation or exceeds the permitted use, you will need to obtain permission directly from the copyright holder. To view a copy of this licence, visit http://creativecommons.org/licenses/by/4.0/ The Creative Commons Public Domain Dedication waiver (http://creativecommons.org/publicdomain/zero/1.0/) applies to the data made available in this article, unless otherwise stated in a credit line to the data. 
Neurolysis, direct nerve repair or nerve grafting in the brachial plexus area might share the reinnervation to many muscle units which might reduce the MRC grade compared to nerve transfer. For those types of surgery, other measures of evaluating outcomes such as secondary surgery might provide different insights into brachial plexus surgery than traditional metrics. Secondary surgery might reflect failure of reinnervation or persistent dysfunction despite re-innervation and might encompass different aspects of outcomes that MRC grading or validated outcomes do not always capture.

Previous studies have reported that body mass index (BMI) may be correlated with the results of nerve transfer in brachial plexus injury patients [17-20]. However, the effect of BMI and neurolysis, direct nerve repair or nerve grafting in brachial plexus injuries is still controversial.

We aimed to examine the correlation between BMI and the presence of secondary surgery to improve upper extremity function after primary reconstruction with neurolysis, direct nerve repair, or nerve grafting procedures in patients with traumatic brachial plexus injury.

\section{Methods}

Study design This study was approved by the local Institutional Review Board. In this retrospective chart review, the medical records of all adult patients with traumatic brachial plexus injury treated by eleven surgeons at two urban hospitals between January 2002 and December 2015 were included. International Classification of Disease 9 (ICD-9) codes within the defined timeframe were used to identify all patients with an injury of the brachial plexus and were cross matched with operative procedures using Current Procedural Terminology (CPT) codes (Additional File 1). We identified 529 patients aged over 18 years with both an ICD-9 and a CPT code for brachial plexus injury; each case was then manually reviewed. Only patients who were initially treated with neurolysis, direct nerve repair, or nerve grafting procedures were included in the study. After excluding patients without a traumatic plexus injury and those who were miscoded, a total of 57 patients were included in our study.

Secondary surgery was defined as any procedure after the first brachial plexus surgery performed in order to improve upper extremity function. The definition of BMI was the weight of the individual (kilograms) divided by the square of the height (meters). A previous study reported that BMI was correlated with mid upper arm circumference and might be representative of the weight of upper extremity [21].

The following data were manually gathered from the medical records:
- Baseline characteristics: age, sex, race, BMI of $30 \mathrm{~kg} /$ $\mathrm{m}^{2}$ or higher [22], and smoking status

- Injury characteristics: mechanism and cause of injury, and injury severity. Motor vehicle accidents, severe lacerations, and falls from a tree were categorized as high energy injuries. We excluded gunshot injuries from high energy injuries because previous studies have suggested that most gunshot injuries are nerve lesions continuity $[6,23]$.

- Initial pattern (C5-C6+/-C7, C8-T1, C5-T1) and associated injuries (e.g., clavicle fracture or shoulder dislocation).

- Treatment characteristics: time from injury to the first brachial plexus surgery and the surgical method)

Characteristics of secondary surgeries were also described in each patient, including indications for and type of secondary surgery, type of primary brachial plexus surgery, level of recovery after primary operation, type of secondary and (if applicable) third and fourth surgeries, and time from first brachial plexus surgery to secondary surgery.

\section{Statistical analysis}

Categorical variables are reported as frequencies and percentages. Non-parametric continuous variables are reported as median and interquartile range (IQR). In bivariate analysis, associations between secondary surgery and categorical variables were calculated using the Fisher's exact test; associations with continuous variables were calculated using the Mann-Whitney U test. A $P$-value of less than 0.05 was considered statistically significant.

The relationship between BMI and secondary surgery was evaluated with advance plots in Lowess line type. If a relationship was non-linear, we categorized patients with BMI of $30 \mathrm{~kg} / \mathrm{m}^{2}$ or higher as "obese" [22].

The power of statistical analysis of association between the determinant and outcome was calculated via a matched case-control study. We interpreted the results if the power of the statistic was at least 0.8 .

Multivariate regression was used to calculate risk ratios and confounders will be adjusted accordingly.

\section{Demographic data}

Of the 57 patients with brachial plexus injury, 39 (69\%) were treated with neurolysis, $15(26 \%)$ with nerve grafting, and $3(5 \%)$ with direct nerve repair. Forty were male (70\%), the median age was 39 (IQR 18-53), most were Caucasian (75\%), and did not smoke (83\%). Most patients (56\%) had a high energy injury. Traction was the most common mechanism of injury (88\%). The median time-to-surgery was 6 months (IQR 2-10 months) (Table 1). 
Table 1 Patient characteristics and factors associated with secondary surgery of neurolysis, direct repair, nerve grafting

\begin{tabular}{|c|c|c|c|c|}
\hline \multirow[t]{3}{*}{ Characteristic } & \multirow{3}{*}{$\begin{array}{l}\text { All } \\
\text { patients } \\
(\boldsymbol{n}=57)\end{array}$} & \multicolumn{2}{|c|}{ Secondary surgery } & \multirow[t]{3}{*}{$\boldsymbol{P}$ Value } \\
\hline & & Yes & No & \\
\hline & & $(\boldsymbol{n}=9)$ & $(\boldsymbol{n}=48)$ & \\
\hline Age, median (SD), y & $39(16)$ & $40(18)$ & $38(16)$ & 0.66 \\
\hline Sex, $n(\%)$ & & & & 0.11 \\
\hline Men & $40(70)$ & $4(44)$ & $36(75)$ & \\
\hline Women & $17(30)$ & $5(56)$ & $12(25)$ & \\
\hline Race, $n(\%)$ & & & & 0.74 \\
\hline White & $43(75)$ & $8(89)$ & $35(73)$ & \\
\hline Black & $6(11)$ & $1(11)$ & $5(10)$ & \\
\hline Hispatic & $1(2)$ & $0(0)$ & $1(2)$ & \\
\hline Unknown & $7(12)$ & $0(0)$ & $7(15)$ & \\
\hline Smoking, $n(\%)^{a}$ & & & & 0.61 \\
\hline Yes & $8(17)$ & $2(25)$ & $6(16)$ & \\
\hline No & $38(83)$ & $6(75)$ & $32(84)$ & \\
\hline Obesity, $n(\%)^{b}$ & & & & $0.007^{*}$ \\
\hline Yes & $11(25)$ & $5(71)$ & $6(16)$ & \\
\hline No & $33(75)$ & $2(29)$ & $31(84)$ & \\
\hline Mechanism, n(\%) & & & & 0.64 \\
\hline Traction & $50(88)$ & $9(100)$ & $41(85)$ & \\
\hline Gunshot & $1(2)$ & $0(0)$ & $1(2)$ & \\
\hline Cut & $6(10)$ & $0(0)$ & $6(13)$ & \\
\hline $\begin{array}{l}\text { High energy injury }{ }^{c} \text {, } \\
\mathrm{n}(\%)\end{array}$ & & & & 0.72 \\
\hline Yes & $32(56)$ & $6(67)$ & $26(54)$ & \\
\hline No & $25(44)$ & $3(33)$ & $22(46)$ & \\
\hline Initial pattern, n(\%) & & & & $>0.99$ \\
\hline $\mathrm{C} 5-\mathrm{C} 6+/-\mathrm{C} 7$ & $25(44)$ & $4(45)$ & $21(44)$ & \\
\hline C8-T1 & $10(17)$ & $1(10)$ & $9(19)$ & \\
\hline C5-T1 & $22(39)$ & $4(45)$ & $18(37)$ & \\
\hline $\begin{array}{l}\text { Associated clavicle } \\
\text { fracture, } n(\%)\end{array}$ & & & & $>0.99$ \\
\hline Yes & $13(23)$ & $2(22)$ & $11(23)$ & \\
\hline No & $44(77)$ & $7(78)$ & $37(77)$ & \\
\hline $\begin{array}{l}\text { Associated shoulder } \\
\text { dislocation, } \mathrm{n}(\%)\end{array}$ & & & & $>0.99$ \\
\hline Yes & $5(9)$ & $1(11)$ & $4(8)$ & \\
\hline No & $52(91)$ & $8(89)$ & $44(92)$ & \\
\hline Surgical method, $\mathrm{n}(\%)$ & & & & 0.82 \\
\hline Neurolysis & $39(69)$ & $6(67)$ & $33(69)$ & \\
\hline Nerve grafting & $15(26)$ & $3(33)$ & $12(25)$ & \\
\hline Direct repair & $3(5)$ & $0(0)$ & $3(6)$ & \\
\hline $\begin{array}{l}\text { Time to surgery, } \\
\text { median (IQR), m }\end{array}$ & $6(2-10)$ & $10(8-15)$ & $5(2-7)$ & 0.05 \\
\hline
\end{tabular}

${ }^{a} n=46 ;{ }^{b} n=44,{ }^{C} H i g h$ energy injury = MVA, severe laceration, falls from a tree' $* P$ value $<0.05$

\section{Results}

Nine out of 57 patients (16\%) underwent secondary surgery after neurolysis (6 of 39 or 15\%), direct nerve repair (0 of 3), or nerve grafting (3 of 15 or $20 \%$ ). The statistical power to identify association between obesity and secondary surgery was 0.8 . Obesity status was significantly associated with the presence of secondary surgery $(P=0.007)$. Bivariate analysis found no significant associations between other variables and the presence of secondary surgery (Table 1).

After controlling for confounders (age, high energy injury, associated shoulder dislocation and associated clavicle fracture) in multivariate regression, the risk ratio of secondary surgery was 6.99 between obese and nonobese patients $(P=0.028$; Table 2$)$.

Some patients did not appear for follow-up, so it was not possible to obtain their outcome data. Although these patients might not have needed secondary surgery, to reduce potential bias, we analyzed only those patients who came to follow-up more than 12 months after primary surgery $(n=30)$ in identifying association between obesity status and the presence of secondary surgery. The risk regression analysis ratio was $10.71(P=0.017)$.

Common secondary surgeries included tendon transfer/tenodesis and local muscle transfer $(67 \% ; 6$ of 9). Five patients (56\%) underwent a third surgery (Table 3).

\section{Discussion}

The purpose of this study was to determine the association between BMI and the presence of secondary surgery after a poor outcome from primary neurolysis, direct nerve repair or nerve grafting in traumatic brachial plexus injury. We found that obese patients with brachial plexus injury had a 6.99 times higher risk of secondary surgery to improve upper extremity function compared to non-obese patients of the same age and with the same injury severity (high energy injury, associated clavicle fracture, associated shoulder dislocation).

Our study has multiple strengths. First, we used a risk regression model to determine the association between obesity status and the presence of secondary surgery adjusted for age and severity of injury. Second, a manual review of the medical records of identified patients was conducted. We believe that we minimized potential errors from coding. Third, data was obtained over a relatively long period (13 years) from two level 1 trauma centers.

A limitation of this study is that it was not possible control for a confounding factor, time to surgery, in computing the risk ratio due to the inadequate size of the sample.

Our findings are consistent with prior studies which have suggested that size might affect the results of nerve transfer in shoulder reconstruction 
Table 2 Association between obesity status and the presence of secondary surgery after adjusting confounder

\begin{tabular}{llll}
\hline Determinant & Risk ratio & $P$ value & $\begin{array}{l}95 \% \text { confident } \\
\text { interval }\end{array}$ \\
\hline Obesity & 6.99 & $0.028^{*}$ & $1.23-39.63$ \\
Age $^{\mathrm{a}}$ & 0.98 & 0.57 & $0.92-1.05$ \\
High energy injury $^{\mathrm{a}}$ & 2.84 & 0.34 & $0.33-24.78$ \\
$\begin{array}{l}\text { Associated shoulder } \\
\text { dislocation }^{\mathrm{a}}\end{array}$ & 4.72 & 0.32 & $0.23-97.62$ \\
Associated clavicle fracture $^{\mathrm{a}}$ & 1.02 & 0.99 & $0.09-11.09$ \\
\hline
\end{tabular}

${ }^{*} P$ value $<0.05,{ }^{a}$ confounder
[17-19, 24], e.g., Socolovsy et al. observed that outcomes of intercostal nerve transfer are better in countries with a lower mean BMI [18]. Other studies have reported that higher BMI is correlated with inferior outcomes after spinal accessory nerve transfer in traumatic brachial plexus palsy $[17,19,20]$, but is not correlated with the outcome of elbow flexion restoration [20]. Unlike the present study, the referenced studies analysed the data using correlation, so the effect of BMI was not explicitly demonstrated and there was no adjustment for the effect of potential confounders.

Table 3 Characteristics of secondary surgery

\begin{tabular}{|c|c|c|c|c|c|c|c|}
\hline Patient & Primary surgery & $\begin{array}{l}\text { Recovery } \\
\text { after } \\
\text { primary } \\
\text { operation }\end{array}$ & $\begin{array}{l}\text { Indication for } \\
\text { secondary surgery }\end{array}$ & $\begin{array}{l}\text { Time between } \\
\text { initial injury to } \\
\text { secondary } \\
\text { surgery } \\
\text { (months) }\end{array}$ & $\begin{array}{l}\text { Secondary } \\
\text { surgery }\end{array}$ & Third surgery & Fourth surgery \\
\hline 1 & $\begin{array}{l}\text { Nerve grafting median } \\
\text { nerve }\end{array}$ & No & $\begin{array}{l}\text { No recovery of } \\
\text { index and thumb } \\
\text { flexion }\end{array}$ & 18.3 & $\begin{array}{l}\text {-Tenodesis } \\
\text { FDP Ring, little } \\
\text { to others }\end{array}$ & & \\
\hline 2 & $\begin{array}{l}\text { Nerve grafting at trunk } \\
\text { level }\end{array}$ & No & $\begin{array}{l}\text { No recovery of } \\
\text { wrist extension }\end{array}$ & 17.5 & $\begin{array}{l}\text {-Tendon } \\
\text { transfer PT to } \\
\text { ECRB }\end{array}$ & $\begin{array}{l}\text { Tendon transfer for finger and } \\
\text { thumb extension }\end{array}$ & \\
\hline 3 & Neurolysis & Partial & $\begin{array}{l}\text { Minimal recovery of } \\
\text { wrist extension, } \\
\text { finger and thumb } \\
\text { extension (not } \\
\text { function) }\end{array}$ & 24.9 & $\begin{array}{l}\text { Tendon } \\
\text { transfer } P L \text { to } \\
\text { EPL, FCR to } \\
\text { ECRB and FCU } \\
\text { to EDC }\end{array}$ & $\begin{array}{l}\text { Tenodesis FDP little to others } \\
\text { for finger flexion, FDS index } \\
\text { tendon transfer fo thumb } \\
\text { extension, wrist fusion for } \\
\text { finger motion }\end{array}$ & \\
\hline 4 & Neurolysis & No & $\begin{array}{l}\text { No recovery of } \\
\text { elbow flexion }\end{array}$ & 41.8 & $\begin{array}{l}\text {-Latissimus } \\
\text { dorsi transfer } \\
\text { to distal } \\
\text { biceps tendon }\end{array}$ & & \\
\hline 5 & Neurolysis & Partial & $\begin{array}{l}\text { Recovery of } \\
\text { shoulder abduction } \\
\text { but no recovery of } \\
\text { shoulder external } \\
\text { rotation }\end{array}$ & 30.8 & $\begin{array}{l}\text {-Latissimus } \\
\text { dorsi transfer } \\
\text { to } \\
\text { infraspinatus } \\
\text { insertion }\end{array}$ & $\begin{array}{l}\text { Reattachment Latissimus dorsi } \\
\text { insertion (loosening over time) }\end{array}$ & $\begin{array}{l}\text { Reattachment } \\
\text { Latissimus } \\
\text { dorsi insertion } \\
\text { (loosening ove } \\
\text { time) }\end{array}$ \\
\hline 6 & Neurolysis & Partial & $\begin{array}{l}\text { Minimal rocovery } \\
\text { of shoulder } \\
\text { abduction }\end{array}$ & 46.1 & $\begin{array}{l}\text { Muscle } \\
\text { transfer to } \\
\text { restore } \\
\text { shoulder } \\
\text { abduction }\end{array}$ & & \\
\hline 7 & Neurolysis & Partial & $\begin{array}{l}\text { Mininal recovery of } \\
\text { elbow flexion (not } \\
\text { function) }\end{array}$ & 24.8 & $\begin{array}{l}\text {-Free } \\
\text { functional } \\
\text { gracilis } \\
\text { muscle } \\
\text { transfer to } \\
\text { distal biceps }\end{array}$ & $\begin{array}{l}\text { Latissimus dorsi transfer for } \\
\text { elbow flexion }\end{array}$ & \\
\hline 8 & Neurolysis & Partial & $\begin{array}{l}\text { Minimal rocovery } \\
\text { of shoulder } \\
\text { abduction }\end{array}$ & 48.3 & $\begin{array}{l}\text { Shoulder } \\
\text { arthrodesis }\end{array}$ & & \\
\hline 9 & $\begin{array}{l}\text { Nerve grafting from fifth } \\
\text { cervical root to } \\
\text { suprascapular nerve and } \\
\text { anterior division of } \\
\text { upper trunk }\end{array}$ & Partial & $\begin{array}{l}\text { Mininal recovery of } \\
\text { shoulder abduction } \\
\text { (not function) }\end{array}$ & 28.6 & $\begin{array}{l}\text {-Transhumeral } \\
\text { amputation }\end{array}$ & Shoulder disarticulation & \\
\hline
\end{tabular}

Time from primary operation to reoperation, median (IQR), m: 12 [9-23]

FDP Flexor Digitorum Profundus, PT Pronator Teres, ECRB Extensor Carpi Radialis Brevis, PL Palmaris Longus, EPL Extensor Pollicis Longus, FCR Flexor Carpi Radialis, FCU Flexor Carpi Ulnaris, EDC Extensor Digitorum Superficialis, FDS Flexor Digitorum Superficialis 
The increased power required to perform motion in the upper extremities might be explained by the higher weight in each part of the upper extremities in obese patients. Additionally, obese status might cause the surgical treatment to be more difficult.

Previously published articles describe an association between age and secondary surgery $[25,26]$. Lee et al. found that greater age was associated with poor deltoid recovery after triceps motor branch transfer [17]. Matejcik et al. reported that best results were achieved in patients younger than 20 years [14]. Other studies have also reported that increased age can negatively affect outcomes after nerve repair and nerve grafting in peripheral nerve injury [27-31]. In investigating the association between obesity status and the presence of secondary surgery, we adjusted for age as a confounding factor (Table 2).

The severity of neural injury might affect the outcome of surgery, so we adjusted for severity of injury as a confounder. We further considered that the initial pattern of the injury $(\mathrm{C} 5-\mathrm{C} 6+/-\mathrm{C} 7, \mathrm{C} 8-\mathrm{T} 1, \mathrm{C} 5-$ T1) might not accurately reflect the severity of neural injury. For that reason, in our cohort we used high energy injury, presence of associated clavicle fracture, and presence of associated shoulder dislocation as indicators of the severity of the injury and we controlled for severity of injury as a confounder (Table 2). High energy injury was defined as involving one of the following: motor vehicle accident, severe laceration, and fall from a tree which we suspected that these has high mechanism with wide zone of injury.

The most common secondary surgeries in our study were tendon transfer/ tenodesis and local muscle transfer (67\%) followed by free functional muscle transfer (11\%), arthrodesis (11\%) and amputation (11\%) (Table 3). This is consistent with previous experience with brachial plexus surgery. Leffert and Pess reported that 74 brachial plexus injured patients underwent 160 tendon transfers and 94 other additional procedures. More than half of the patients achieved good results [32].

\section{Conclusions}

In obese patients with a brachial plexus injury who undergo neurolysis, direct nerve repair or nerve grafting, the risk of secondary surgery to improve upper extremity function is seven times that of non-obese patients of the same age and with the same severity of injury. A portion of this increased risk may be due to the challenge of powering a heavier upper extremity. A weight reduction program could be considered as the part of the preoperative strategy.

\section{Supplementary information}

Supplementary information accompanies this paper at https://doi.org/10. 1186/s12893-020-00737-4

Additional file 1. List of ICD-9 and CPT codes to identify all patients with traumatic brachial plexus injury who underwent neurolysis, direct nerve repair, or nerve grafting.

\section{Abbreviations}

MRC: Medical research council; BMI: Body mass index; ICD-9: International classification of disease 9; CPT: Current procedural terminology;

IQR: Interquartile range; FDP: Flexor digitorum profundus; PT: Pronator teres; ECRB: Extensor carpi radialis brevis; PL: Palmaris longus; EPL: Extensor pollicis Iongus; FCR: Flexor carpi radialis; FCU: Flexor carpi ulnaris; EDC: Extensor digitorum superficialis; FDS: Flexor digitorum superficialis; ECRL: Extensor carpi radialis longus

\section{Acknowledgements}

This study was supported by Department of Orthopaedic Surgery, Massachusetts General Hospital, Boston, MA. The authors are grateful to G. Lamar Robert, PhD, for reviewing the manuscript.

\section{Ethics approval and and consent to participate}

This study was approved by Institutional Review Board in Partners Human Research protocol number 2017P000694. All procedures were conducted in accordance with the ethical standards of the responsible committees on human experimentation (institutional and national) and with the Helsinki Declaration of 1975, as revised in 2008. Written informed consent was obtained from all individual participants included in the study.

\section{Authors' contributions}

PA and NC initiated study conception and design. PA performed the data collection and acquisition of data. PA and KO performed the data analysis. $\mathrm{PA}, \mathrm{KO}, \mathrm{KE}, \mathrm{JW}, \mathrm{NC}$ and SL interpreted the data. PA wrote the manuscript. $\mathrm{KO}, \mathrm{KE}, J \mathrm{~W}, \mathrm{NC}$ and SL edited the manuscript. PA had a role in critical revision. All authors have read and approved the manuscript.

\section{Funding}

No specific grant was received from any funding agency in the public, commercial, or not-for-profit sectors.

Availability of data and materials

The datasets used and/or analyzed during the current study are available from the corresponding author on reasonable request.

Consent for publication

Not Applicable.

\section{Competing interests}

The authors declare that they have no competing interests.

\section{Author details}

'Department of Orthopaedic Surgery, Massachusetts General Hospital, Boston, MA, USA. ${ }^{2}$ Department of Orthopaedics, Faculty of Medicine, Chiang Mai University, Chiang Mai, Thailand. ${ }^{3}$ Musculoskeletal Science and Translational Research Center, Chiang Mai University, Chiang Mai, Thailand.

Received: 5 June 2019 Accepted: 6 April 2020

Published online: 15 April 2020

\section{References}

1. Limthongthang RBA, Songcharoen P, Osterman AL. Adult brachial plexus injury evaluation and management. Orthop Clin N Am. 2013;44:591-603.

2. Kline DG, Tiel RL. Direct plexus repair by grafts supplemented by nerve transfers. Hand Clin. 2005:21(1):55-69, vi.

3. Sakellariou VI, Badilas NK, Stavropoulos NA, Mazis G, Kotoulas HK, Kyriakopoulos S, et al. Treatment options for brachial plexus injuries. ISRN Orthop. 2014;2014:314137.

4. Dubuisson AS, Kline DG. Brachial plexus injury: a survey of 100 consecutive cases from a single service. Neurosurgery. 2002;51(3):673-82 discussion 82-3. 
5. Spinner RJ, Kline DG. Surgery for peripheral nerve and brachial plexus injuries or other nerve lesions. Muscle Nerve. 2000;23(5):680-95.

6. Kim DH, Murovic JA, Tiel RL, Kline DG. Mechanisms of injury in operative brachial plexus lesions. Neurosurg Focus. 2004;16(5):E2.

7. Kanaya F, Gonzalez M, Park CM, Kutz JE, Kleinert HE, Tsai TM. Improvement in motor function after brachial plexus surgery. J Hand Surg Am. 1990;15(1):30-6.

8. Belzberg AJ, Dorsi MJ, Storm PB, Moriarity JL. Surgical repair of brachial plexus injury: a multinational survey of experienced peripheral nerve surgeons. J Neurosurg. 2004;101(3):365-76.

9. Moran SL, Steinmann SP, Shin AY. Adult brachial plexus injuries: mechanism, patterns of injury, and physical diagnosis. Hand Clin. 2005; 21(1):13-24.

10. Shin AY, Spinner RJ, Steinmann SP, Bishop AT. Adult traumatic brachial plexus injuries. J Am Acad Orthop Surg. 2005;13(6):382-96.

11. Nagano A. Treatment of brachial plexus injury. J Orthop Sci. 1998;3(1):71-80.

12. Malessy MJ, van Duinen SG, Feirabend HK, Thomeer RT. Correlation between histopathological findings in C -5 and C -6 nerve stumps and motor recovery following nerve grafting for repair of brachial plexus injury. J Neurosurg. 1999;91(4):636-44.

13. Matsuyama T, Okuchi $K$, Akahane $M$, Inada $Y$, Murao $Y$. Clinical analysis of 16 patients with brachial plexus injury. Neurol Med Chir (Tokyo). 2002;42(3): 114-21 discussion 22.

14. Matejcik V, Penzesova G. Follow-up evaluation of neurolysis of brachial plexus and peripheral nerves of upper extremities. Bratisl Lek Listy. 2004; 105(12):424-7.

15. Haninec $P$, Samal F, Tomas R, Houstava L, Dubovwy P. Direct repair (nerve grafting), neurotization, and end-to-side neurorrhaphy in the treatment of brachial plexus injury. J Neurosurg. 2007;106(3):391-9.

16. Moor BK, Haefeli M, Bouaicha S, Nagy L. Results after delayed axillary nerve reconstruction with interposition of sural nerve grafts. J Shoulder Elb Surg. 2010;19(3):461-6.

17. Lee JY, Kircher MF, Spinner RJ, Bishop AT, Shin AY. Factors affecting outcome of triceps motor branch transfer for isolated axillary nerve injury. J Hand Surg Am. 2012;37(11):2350-6

18. Socolovsky M, Paez MD. A literature review of intercostal-tomusculocutaneous-nerve transfers in brachial plexus injury patients: does body mass index influence results in eastern versus Western countries? Surg Neurol Int. 2013;4:152.

19. Socolovsky M, Di Masi G, Bonilla G, Malessy M. Spinal to accessory nerve transfer in traumatic brachial plexus palsy: is body mass index a predictor of outcome? Acta Neurochir. 2014;156(1):159-63.

20. Socolovsky M, Martins RS, Di Masi G, Bonilla G, Siqueira MG. Influence of body mass index on the outcome of brachial plexus surgery: are there any differences between elbow and shoulder results? Acta Neurochir. 2014; 156(12):2337-44

21. Khadivzadeh T. Mid upper arm and calf circumferences as indicators of nutritional status in women of reproductive age. East Mediterr Health J. 2002;8(4-5):612-8.

22. Jensen MD, Ryan DH, Apovian CM, Ard JD, Comuzzie AG, Donato KA, et al. 2013 AHA/ACC/TOS guideline for the management of overweight and obesity in adults: a report of the American College of Cardiology/American Heart Association task force on practice guidelines and the Obesity Society. J Am Coll Cardiol. 2014;63(25 Pt B):2985-3023.

23. Vrettos BC, Rochkind S, Boome RS. Low velocity gun shot wounds of the brachial plexus. J Hand Surg Br. 1995;20(2):212-4.

24. Benitez Brito N, Suarez Llanos JP, Fuentes Ferrer M, Oliva Garcia JG, Delgado Brito I, Pereyra-Garcia Castro F, et al. Relationship between mid-upper arm circumference and body mass index in inpatients. PLoS One. 2016;11(8): e0160480.

25. Kallio PK, Vastamaki M, Solonen KA. The results of secondary microsurgical repair of radial nerve in 33 patients. J Hand Surg Br. 1993;18(3):320-2.

26. Ricardo M. Surgical treatment of brachial plexus injuries in adults. Int Orthop. 2005;29(6):351-4

27. Ruijs AC, Jaquet JB, Kalmijn S, Giele H, Hovius SE. Median and ulnar nerve injuries: a meta-analysis of predictors of motor and sensory recovery after modern microsurgical nerve repair. Plast Reconstr Surg. 2005;116(2):484-94 discussion 95-6.

28. Kalomiri DE, Soucacos PN, Beris AE. Nerve grafting in peripheral nerve microsurgery of the upper extremity. Microsurgery. 1994;15(7): 506-11.
29. Roganovic Z, Petkovic S. Missile severances of the radial nerve. Results of 131 repairs. Acta Neurochir 2004;146(11):1185-1192.

30. Kallio PK, Vastamaki M. An analysis of the results of late reconstruction of 132 median nerves. J Hand Surg Br. 1993;18(1):97-105.

31. Vastamaki M, Kallio PK, Solonen KA. The results of secondary microsurgical repair of ulnar nerve injury. J Hand Surg Br. 1993;18(3):323-6.

32. Leffert RD, Pess GM. Tendon transfers for brachial plexus injury. Hand Clin. 1988:4(2):273-88.

\section{Publisher's Note}

Springer Nature remains neutral with regard to jurisdictional claims in published maps and institutional affiliations.
Ready to submit your research? Choose BMC and benefit from:

- fast, convenient online submission

- thorough peer review by experienced researchers in your field

- rapid publication on acceptance

- support for research data, including large and complex data types

- gold Open Access which fosters wider collaboration and increased citations

- maximum visibility for your research: over $100 \mathrm{M}$ website views per year

At BMC, research is always in progress.

Learn more biomedcentral.com/submissions 